Удк 338.48

DOI https://doi.org/10.32851/2708-0366/2021.7.3

Kim Г.В.

кандидат економічних наук, доцент, ДВНЗ «Ужгородський національний університет» ORCID: https://orcid.org/0000-0002-6201-9589

Kish Galyna

Uzhhorod National University

\title{
СУЧАСНІ ТУРИСТИЧНІ ТЕНДЕНЦІЇ В ПОСТПАНДЕМІЧНИЙ ПЕРІОД
}

\section{MODERN TOURISM TRENDS IN THE POST PANDEMIC PERIOD}

Статтю присвячено аналізу розвитку туристичної галузі під час глобальної пандемії COVID-19, щзо кардинально вплинула на всіх гравців туристичного ринку. Очевидним є те, щзо туристична галузь відчула значний негативний вплив. Проте, як $і$ будь-який процес чи явище, пандемія може принести не лише негативні наслідки, а й стимулювати позитивні зрушення в різних сферах, шзо остаточно переведуть туристичну сферу на новий рівень розвитку. Зокрема, у статті йдеться про питання безпеки та гігієни, підтримку сталого розвитку, а також використання новітніх інформаційних технологій у туристичній сфері. Украй важливим є відновлення туристичного сектору, при цььому із забезпеченням безпеки, справедливості й відсутності негативного впливу на клімат.

Ключові слова: туризм, туристична сфера, криза, пандемія, постпандемічний період.

Статья посвящена анализу развития туристической отрасли во время глобальной пандемии COVID-19, которая кардинально повлияла на всех игроков туристического рынка. Очевидно, что туристическая отрасль почувствовала значительное негативное влияние. Однако, как и любой процесс или явление, пандемия может принести не только негативные последствия, но и стимулировать положительные сдвиги в различньх сферах, что окончательно переведут туристическую сферу на новый уровень развития. В частности, в статье идет речь о вопросах безопасности и гигиень, поддержке устойчивого развития, а также использовании новейших информационных технологий в туристической сфере. Крайне важным является восстановление туристического сектора, при этом с обеспечением безопасности, справедливости и отсутствия негативного влияния на климат.

Ключевые слова: туризм, туристическая сфера, кризис, пандемия, постпандемический период.

The article is devoted to the analysis of the tourism industry development during the global pandemic COVID-19, which dramatically affected on all players of tourism market. It is obvious that the tourism industry has experienced a significant negative impact. However, like any process or phenomenon, a pandemic can bring not only negative consequences, but also stimulate positive changes in various areas, that will finally transfer the tourism sector to a new level of development. In particular, the article deals with issues of safety and hygiene, support for sustainable development (reducing the share of business tourism, intensification of domestic individual tourism, emphasis on local and healthy food), also the use of the modern information technologies in the tourism sector (contactless payments, service automation, chat bots, voice control, voice search, voice booking, recognition technologies, virtual and augmented reality). A portrait of the future travelers has been formed - these are independent travelers who are well versed in digital technologies, have an interest in cultural values and already have experience in researching tourism destinations. The tourism industry, despite significant losses during the pandemic, has the potential for development, after crises and falls with a properly planned strategy of action always begins to rise. Of course, the recovery will be gradual, the first time, obviously, will be popular domestic and ecological tourism. It is extremely important to restore the tourism sector, while ensuring security, justice and the absence of negative effects on the climate.

The purpose of the article is to review the situation in which the tourism sector found itself during the global pandemic and to identify the main positive post-pandemic trends in the tourism 
sector that will unprecedentedly change the industry as a whole. The methodological and informational basis of the work is scientific works, materials of periodicals, official sites and analytical reviews of the IMF, UNWTO. Methods of analysis, synthesis, comparison, grouping and generalization were used.

Key words: tourism, tourism sector, crisis, pandemic, post-pandemic period.

Постановка проблеми. Туристична сфера зазнала найбільшого впливу серед інших галузей після безпрецедентної надзвичайної ситуації в галузі охорони здоров'я, соціальної та економічної ситуації на тлі спалаху пандемії COVID-19.

Потоки міжнародних туристів у 2020 р. зменшилися на 74\% порівняно 3 попереднім роком через широко розповсюджені обмеження на подорожі та значне падіння попиту. Колапс міжнародних подорожей сприяв утратам в експортних доходах на 1,3 трлн дол. США, що більше ніж у 11 разів за втрати, зафіксовані під час світової економічної кризи 2009 р.

Якщо проаналізувати динаміку показників міжнародних прибуттів, то можна побачити, що в Азії та Тихоокеанському регіоні у 2020 р. кількість іноземних туристів зменшилася на 84\%, що майже на 300 млн менше, ніж у попередньому році. Близький Схід та Африка зафіксували падіння прибулих на 75\%. Прибуття в Свропу зменшились на 70\%, що на 500 млн менше іноземних туристів, тоді як в Америку спостерігалося падіння на 69\% [4].

Згідно $з$ останніми туристичними даними Всесвітньої туристичної організації (ЮНВТО), у період із січня по жовтень 2020 р. туристичні локації приймали на 900 млн менше міжнародних туристів порівняно з аналогічним періодом 2019 р. Це призвело до втрати 935 млрд дол. США від міжнародного туристичного експорту, що більше у 10 разів, аніж утрати 2009 р. під впливом світової економічної кризи.

За даними UNWTO, кількість міжнародних прибуттів зменшилася на 70-75\% протягом 2020 р. Глобальний туризм повернувся до рівня 30-річної давності, тобто це зменшення туристичних потоків на 1 млрд осіб і втрата майже 1,1 трлн дол. США надходжень. Це масове падіння туризму внаслідок пандемії призвело до економічних утрат світового ВВП на 2 трлн дол. США [4].

У результаті протягом перших кількох місяців пандемії формування глобальної туристичної системи перейшло від надтуризму до недотуризму. Загальне переконання полягає у тому, що туризм відновиться, як і в попередні кризи. Однак є багато доказів того, що COVID-19 буде більш трансформативним для туристичного сектору. Уряди лише починають розуміти, що на відміну від інших секторів бізнесу доходи від туризму втрачаються назавжди, оскільки непроданий потенціал, наприклад розміщення, не може продаватися в наступні роки, що має відповідні наслідки для зайнятості у цьому секторі.

Важливо зазначити, що в минулому світовий туризм зазнав багато криз. Між 2000 і 2015 рр. основними руйнівними подіями були теракти 11 вересня 2001 р., спалах важкого гострого респіраторного синдрому (ГРВІ) (2003р.), глобальна економічна криза, що розгорнулася в 2008-2009 pр., та Близькосхідний респіраторний синдром 2015 р. (MERS). Жоден із них не призвів до довгострокового спаду світового розвитку туризму, лише ГРВІ $(-0,4 \%)$ та світова економічна криза $(-4,0 \%)$ призвели до спаду у міжнародних прибуттях. Це свідчить про те, що туризм як система стійкий до зовнішніх потрясінь. Однак є багато доказів того, що вплив та відновлення від пандемії COVID-19 будуть безпрецедентними.

Загальний попит залишається у цілому слабким, незважаючи на незначне поліпшення на деяких ринках. Для прикладу, США, Німеччина та Франція демонструють деякі ознаки відновлення протягом останніх місяців. Усе більша кількість регіонів послаблює або скасовує обмеження на подорожі. Згідно з останніми дослідженнями 
ЮНВТО, частка закритих туристичних дестинацій знизилася з 82\% наприкінці квітня 2020 р. до $18 \%$ на початку 2021 р.

Проте в результаті експертного опитування ЮНВТО визначено невтішні перспективи відновлення. Більшість експертів не бачить можливості відновлення до допандемічного рівня до 2023 р. Насправді 43\% респондентів вказують на 2023 р., тоді як 41\% очікують повернення до рівня 2019 р. в 2024 р. або пізніше.

Очікується, що поступове розповсюдження вакцини проти COVID-19 допоможе відновити довіру споживачів, зменшить обмеження на подорожі та повільно нормалізує сферу туризму.

Аналіз останніх досліджень і публікацій. Значну увагу дослідженню питань розвитку туристичної галузі під час пандемії COVID-19 приділяють багато вчених, зокрема: І.О. Панова, О. Губанова, Н. Шуптар-Пориваєва, О. Андрущенко, Ю. Мельницька, В. Непочатенко та ін. Більшість науковців досліджує стан галузі в даній кризовій ситуації, прогнозує негативні наслідки та формує можливі прогнози розвитку туристичної сфери. Проте недостатньо дослідженими залишаються наслідкові тенденції, які формувалися у світовому просторі, а під час пандемії отримали поштовх до підсилення. Саме вони повернуть туристичну сферу майбутнього у нове русло.

Формулювання цілей статті. Мета дослідження полягає в огляді ситуації, в якій опинилася туристична сфера під час глобальної пандемії, та визначенні основних позитивних постпандемічних тенденцій у туристичній сфері, які безпрецедентно змінять у цілому всю галузь. Методологічною та інформаційною основою роботи $є$ наукові праці, матеріали періодичних видань, офіційних сайтів та аналітичних обзорів IMF, UNWTO. У дослідженні використано методи аналізу, синтезу, порівняння, групування та узагальнення

Виклад основного матеріалу. Попереду світ усе ще чекають серйозні проблеми, починаючи з невизначеної тривалості пандемії та завершуючи обмеженнями на пересування, і все це в контексті глобальної економічної рецесії. Країни в усьому світі впроваджують низку заходів для мінімізації наслідків пандемії COVID-19 і стимулювання відновлення туристичного сектору.

3 іншого боку, пандемію COVID-19 можна розглядати як можливість критично переглянути траєкторію розвитку туризму та перейти на новий рівень розвитку туристичної галузі.

Важливо стежити за сучасними туристичними тенденціями у відповідь на зміну поведінки споживачів у результаті пандемії. Очевидно, що більшість закономірностей виникла в результаті більш загальних змін у поведінці туристів, а пандемія лише підсилила їх вагомість:

1. Підвищена увага до питань безпеки та гігієни: чистота, гігієна рук, прибирання готельних номерів, протоколи з попередження ризику ураження вірусом (наприклад, програма Hilton CleanStay спільно з виробником антисептика Lysol).

Для прикладу, Сінгапур запустив програму перевірки готелів по всьому світі, що передбачає видачу сертифікатів чистоти та здоров'я певним засобам розміщення, які відповідають семи критеріям. На приміщенні такого засобу розміщення встановлюють позначку програми SG Clean, що гарантує впевненість місцевих жителів і відвідувачів. До переліку критеріїв входить призначення менеджера SG Clean, що контролює процеси в приміщенні, відповідає за температурний скринінг і контроль за здоров'ям працівників, залучення зовнішніх постачальників і підрядників, заходи 3 дотримання норм чистоти та гігієни, забезпечує відповідність рекомендаціям щодо охорони здоров'я та безпеки туристів, а також виконання наказів уряду, пов'язаних із COVID-19. Першим готелем, який пройшов сертифікацію, є Grand Hyatt Singapore [9].

У Португалії готелі, ресторани, туристичні комплекси, турфірми та контори мають можливість отримати сертифікат Clean \& Safe, який надасть туристам упевненості у 
власній безпеці і стане гарантією того, що цей заклад дотримується усіх необхідних вимог щодо запобігання поширенню COVID-19. Термін дії сертифіката - один рік, і він є безкоштовним. Мадридська асоціація готел'єрів разом з Агентством із туризму Каталонії також розробляють власну систему сертифікації COVID-19 Free. Документ надаватиметься за дотримання гігієнічних протоколів із прибирання номерів, кухонь, громадських приміщень у готелях [10].

2. Зменшення частки бізнес-туризму через проведення більшості бізнес-конференцій в онлайн-режимі. За словами більшості українських експертів, популярними напрямами після виходу з карантину стануть короткі програми вихідного дня за низькою ціною, сімейний відпочинок, лікувальний туризм. У даних умовах відпочинок у сільських садибах, мандрівки екологічними стежками, велоподорожі та сплави на байдарках можуть стати трендом туристичного сезону - 2021. Це й оздоровлення, й відпочинок, і водночас обмеження контактів з іншими людьми, що дає змогу забезпечувати відповідні заходи з профілактики власного здоров'я, особливо в умовах пандемії.

Відеоконференції, втрачена роками можливість зменшити попит на транспорт широко застосовуються працівниками домашніх офісів, включаючи студентів, примушених до дистанційного навчання, та бізнес-туристів, які уникають необов'язкових авіаперевезень. Навіть обміни на високому рівні, такі як засідання лідерів G20 26 березня 2020 р., уперше були організовані за допомогою відеоконференції (Європейська рада, 2020).

3. Круїзи в новому форматі. Німецька компанія TUI Cruises продовжує використовувати «пасажирські крейсери» за призначенням. Круїзний лайнер відчалює від німецького узбережжя, курсує кілька днів морем і повертається назад. Туристи вже назвали такі морські круїзи «мандрівкою в нікуди». До кінця серпня TUI Cruises планує подовжити морські екскурсії до семи днів, демонструючи туристам види на узбережжя Норвегії, Швеції та Фінляндії [1].

4. Активізація індивідуального туризму.

5. Розвиток внутрішнього туризму, занурення в місцеву культуру. Наприклад, Італія готує програму стимулювання внутрішнього туризму: громадянам відшкодують частину витрат на відпустку (зараз обговорюється сума у 350-500 євро), проведену у власній країні. Потужні китайські туроператори розробили й успішно продають туристичні пакети для своїх клієнтів, серед яких - програми відвідування мегаполісів, островів, відомих гірських курортів і регіонів природних заповідників. Лише на травневі свята у КНР було зареєстровано рекордну кількість внутрішніх мандрівок 115 млн, що повернуло галузі 6,79 млрд доларів. Влада заборонила групові тури за кордон, відтепер рушійною силою галузі став індивідуальний туризм [6].

У Державному агентстві розвитку туризму України працюють над проєктом розвитку і популяризації внутрішнього туризму, адже саме з нього має початися відродження туристичної галузі після пандемії коронавірусу.

Ринки, орієнтовані на внутрішній автомобільний туризм (особливо ті, які пропонують відпочинок на свіжому повітрі), ймовірно, будуть найстійкішими до будь-якого спаду активності. Цілком можлива активізація саме автомобільного туризму по Україні в літній сезон [13].

6. Здорове, органічне харчування, local food. Загалом туризм стане більш екологічним. Через зниження авіаперевезення скоротяться викиди СО2. Так, на початку квітня 2020 р. викиди скоротилися на 60\% порівняно з аналогічним періодом минулого року. Також $є$ ймовірність, що з відновленням рейсів авіакомпанії перейдуть на більш екологічне паливо.

7. Безконтактні платежі. За допомогою глобальних сервісів Google Pay, Apple Pay та ін. туристи мають можливість розраховуватися безконтактно за допомогою смартфону, розумного годинника чи іншого пристрою, який підтримує технологію NFC, 
у будь-якому куточку світу, де $є$ безконтактні термінали, навіть у тих країнах, де зазначені глобальні сервіси ще не представлені [2].

8. Чат-боти, роботи, автоматизація обслуговування.

9. Технології розпізнавання, штучний інтелект. Для прикладу, додаток «Дій удома», який призначений для контакту 3 особою та контролю за дотриманням обов'язкової самоізоляції після повернення з-за кордону в Україну. В основі - зарубіжний досвід країн, які використовують цифрові інструменти для забезпечення безпеки громадян у період пандемії. Перше фото, яке зроблене під час авторизації у додатку, вважатиметься еталонним. Саме з ним у подальшому штучний інтелект порівнюватиме наступні фото.

10. Голосовий пошук, голосові бронювання, голосове управління (заклади розміщення). Amazon Alexa, Google Home, Apple Siri, Bixby i Microsoft Cortana домінують на ринку цифрових голосових помічників. У цьому році у світі використовується понад 4 млрд мобільних помічників, більшість 3 яких мають функціональність для виконання замовлень на поїздки (Juniper Research).

Microsoft стверджує, що мандрівники у Великобританії все частіше шукають готелі за допомогою свого цифрового помічника Cortana на мобільних пристроях: пошук готелів збільшився на $343 \%$ за рік, а пошук авіаквитків - на 277\%.

Сучасний споживач онлайн-подорожей вимагає інтуїтивно зрозумілого планування подорожей, включаючи можливість пошуку і бронювання готелів за допомогою голосового пошуку. Цифрові голосові помічники вже дають змогу споживачам подорожей шукати проживання, а в деяких випадках - бронювати готелі. Amazon Alexa, що працює з Kayak.com, пропонує бронювання готелів за допомогою голосового пошуку для будь-якого споживача подорожей з Kayak.com проте все ж існують деякі помітні обмеження для цієї технології:

- Alexa не дає змоги відвідувачам порівнювати ціни, натомість повертаючи тільки один високоранговий результат.

- Інтеграція голосового пошуку Kayak вимагає від користувачів наявності облікового запису Kayak; нині це впливає тільки на результати Kayak, хоча це може поширитися й на результати Google, якщо вони розширять цю функцію у майбутньому.

- Окрім Amazon, усі основні гравці у сфері розпізнавання голосу (Apple, Google i Microsoft) вже включили голосовий пошук готелів та працюють над додатками для користувачів, щоб завершити бронювання.

11. Віртуальна реальність та доповнена реальність. Музеї, галереї та інформаційні центри переважно перейшли на віртуальні тури, відеоблоги у соціальних мережах та освітній контент. Ермітаж та компанія Apple спільно підготували п'ятигодинну подорож по музею, у Луврі, скориставшись віртуальною екскурсію, туристи можуть ознайомитися 3 найпопулярнішими експонатами музею, оглянувши кожну локацію у 3D-форматі, та отримати додаткову інформацію [11].

Під час локдауну зросла популярність віртуальних екскурсій та вдвічі збільшився інтерес до онлайн-подорожей. Сучасні технології дають змогу організувати інтерактивну екскурсію для групи у 10-15 осіб, яку проводить справжній екскурсовод, що має можливість не лише розповідати про видатні пам'ятки, а й підтримувати з людьми онлайн-діалог. Сьогодні Інтернет-екскурсії проводяться в ботанічному саду міста Кембридж, завдяки ним туристи можуть побачити онлайн Ніагарський водоспад, Колізей $\mathrm{i}$ Білий дім, відвідати запорізьку Хортицю [3].

На основі цих тенденцій можна сформувати портрет мандрівників майбутнього це незалежні мандрівники, які добре обізнані у цифрових технологіях, мають зацікавленість у культурних цінностях і вже мають досвід дослідження дестинації.

Ці позитивні зміни можуть розглядатися як попередники змін на більш широкому рівні, що призведе до переорієнтації глобальної туристичної системи на сталий розви- 
ток, а не до «зростання» як абстрактного поняття, що приносить користь небагатьом. 3 упевненістю можна сказати, що найближчим часом можна буде спостерігати нові креативні рішення у туристичній сфері, народжені необмеженою уявою, натхненням, глобалізацією та вільним ринком.

Висновки. Міжнародні прибуття впали на 72\% за перші десять місяців 2020 р. Обмеження на поїздки, низька довіра споживачів та глобальна боротьба за стримування вірусу COVID-19 - усе це сприяло найгіршому року в історії туризму.

Розширені сценарії на 2021-2024 pр., представлені спеціалізованим агентством ООН з туризму, вказують на вірогідність туристичного спаду в другій половині 2021 p. Тим не менше повернення до рівня 2019 р. $з$ погляду міжнародних прибуттів може зайняти від двох із половиною до чотирьох років.

Можна припустити, що переважна кількість покращень в організації туризму базуватиметься на організації віртуальних рішень і дистанційної роботи, а також на проведенні освітніх програм, які в багатьох країнах залишатимуться в режимі онлайн і після кризи COVID-19.

Отже, зрозуміло, що туристична галузь, незважаючи на значні втрати під час пандемії, має потенціал для розвитку: після криз та падінь за правильно спланованої стратегії дій завжди починається підйом. Звичайно, відновлення відбуватиметься поступово, спочатку, очевидно, будуть популярними внутрішній та екологічний туризм.

\section{Список використаних джерел:}

1. Cruise ships are back. Welcome aboard the voyage of the damned. URL: https://www.wired.co.uk/ article/cruise-ships-coronavirus-recovery (дата звернення: 31.05.2021).

2. Бондаренко Л.П., Ярошевич Н.Б., Тарабінович А.Б. Практика використання безконтактних платежів в Україні та світі. Ефективна економіка. 2019. № 2. URL: http://www.economy.nayka.com.ua/?op=1\&z=6902 DOI: 10.32702/2307-2105-2019.2.52 (дата звернення: 31.05.2021).

3. Британські гіди викликають посмішки і сльози радості онлайн-екскурсіями по ботанічному саду (відео). URL: https://world.segodnya.ua/ua/world/wnews/britanskie-gidy-vyzyvayut-uly bki-i-slezy-radosti-onlayn-ekskursiyami-po-botanicheskomu-sadu-video-1428288.html (дата звернення: 31.05.2021).

4. Всесвітня туристична організація. URL: https://www.unwto.org/covid-19-and-tourismstatistics (дата звернення: 31.05.2021).

5. Губанова О., Шуптар-Пориваєва Н., Андрущенко О. Стимулювання туристичної діяльності в умовах коронавірусної кризи. Таврійський науковий вісник. Серія «Економіка». № 5. C. 16-23. URL: https://doi.org/10.32851/2708-0366/2021.5.2 (дата звернення: 31.05.2021).

6. Карантин. Як світ рятує туристичну галузь. URL: https://www.ukrinform.ua/rubrictourism/3090351-karantin-ak-svit-ratue-turisticnu-galuz.html (дата звернення: 31.05.2021).

7. Мельницька Ю. Коли закінчиться карантин: Три сценарії розвитку міжнародного туризму після пандемії. URL: https://investory.news/koli-zakinchitsya-karantin-tri-scenarii-rozvitkumizhnarodnogo-turizmu-pislya-pandemii/ (дата звернення: 31.05.2021).

8. Непочатенко B.O. COVID-19 і туризм: аналіз ситуації та економічні шляхи виходу з кризи. Ефективна економіка. 2020. № 7. URL: http://www.economy.nayka.com.ua/?op=1\&z=8079 (дата звернення: 31.05.2021). DOI: 10.32702/2307-2105-2020.7.52.

9. Пандемія COVID-19 і іï наслідки у сфері туризму в Україні: спеціальний звіт. URL: http://www.ntoukraine.org/assets/files/EBRD-COVID19-Report-UKR.pdf (дата звернення: 31.05.2021).

10. Панова I.О. Туризм під час пандемії: наслідки та перспективи. Бізнес Інформ. 2020. № 5. C. 226-232. DOI: https://doi.org/10.32983/2222-4459-2020-5-226-232 (датазвернення:31.05.2021).

11. ТОП-7 віртуальних екскурсій музеями світу. URL: https://naurok.com.ua/post/top-7virtualnih-ekskursiy-muzeyami-svitu (дата звернення: 31.05.2021).

12. Туризм часів пандеміï: що буде з галуззю у 2021 році URL: https://www.epravda.com.ua/ columns/2020/12/3/668768/ (дата звернення: 31.05.2021).

13. Туризм після пандемії. Чи є перспектива? URL: https://rst.if.ua/2020/05/01/turyzm-pislyapandemiyi-chy-ye-perspektyva/ (дата звернення: 31.05.2021). 


\section{References:}

1. Cruise ships are back. Welcome aboard the voyage of the damned. Available at: https://www.wired.co.uk/article/cruise-ships-coronavirus-recovery (accessed 31 May 2021)

2. Bondarenko L.P., Yaroshevych N.B., Tarabinovych A.B. (2019) Praktyka vikoristanja bezkontaktnih platezhiv v Ukraina ta sviti [Practice of using contactless payments in Ukraine and the world]. Efektyvna ekonomika [Online], vol. 2. Available at: http://www.economy.nayka.com.ua/ ?op=1\&z=6902 (accessed 31 May 2021). DOI: 10.32702/2307-2105-2019.2.52.

3. Britanski gidu vuklukaut posmishky i sljozy radosty onlain ekskursijamy po botanichnomu sadu [British guides bring smiles and tears of joy online tours of the botanical garden] (video). Available at: https://world.segodnya.ua/ua/world/wnews/britanskie-gidy-vyzyvayut-ulybki-i-slezy-radosti-onlayn-ekskursiyami-po-botanicheskomu-sadu-video-1428288.html (accessed 31 May 2021).

4. UNWTO. Official site. Available at: https://www.unwto.org/covid-19-and-tourism-statistics (accessed 31 May 2021).

5. Gubanova O., Shuptar-Poryvaeva N., Andrushchenko O. (2020) Stumuluvanja turistichnoi dialnosty v umovah coronavirusnoi kryzy [Stimulation of tourist activity in the conditions of coronavirus crisis]. Taurida Scientific Herald. Economics, no. 5, p. 16-23. Available at: https://doi.org/ 10.32851/2708-0366/2021.5.2 (accessed 31 May 2021).

6. Karantyn. Jak svit rjatuje turistichnu galuz [Quarantine. How the world saves the tourism industry]. Available at: https://www.ukrinform.ua/rubric-tourism/3090351-karantin-ak-svit-ratue-turisticnu-galuz.html (accessed 31 May 2021).

7. Melnytska Yu. (2020) Koly zakinchitsja karantin: tri scenario rozvitku turismu pislja pandemii [When the quarantine will end: Three scenarios for the development of international tourism after the pandemic]. Available at: https://investory.news/koli-zakinchitsya-karantin-tri-scenarii-rozvitku-mizhnarodnogo-turizmu-pislya-pandemii/ (accessed 31 May 2021).

8. Nepochatenko V. (2020) Covid-19 i turism: analis sutuacii ta ekonomichni shlzhy vihodu z krizi [Covid-19 and tourism: analysis of economic situation and ways out of crisis]. Efektyvna ekonomika [Online], vol. 7. Available at: http://www.economy.nayka.com.ua/?op=1\&z=8079 (accessed 31 May 2021). DOI: 10.32702/2307-2105-2020.7.52.

9. Pandemija COVID-19 i ii naslidky u sfery turismu v Ukraini: specalnij zvit [The COVID-19 pandemic and its implications for tourism in Ukraine: a special report] Available at: http://www.ntoukraine.org/assets/files/EBRD-COVID19-Report-UKR.pdf (accessed 31 May 2021).

10. Panova Iryna (2020) Turism pid chas pandemii: naslidky ta perpektivy [Tourism During a Pandemic: Implications and Prospects]. Business Inform, no. 5, p. 226-232. DOI: https://doi.org/10.32983/2222-4459-2020-5-226-232.

11. TOP-7 vitrualnih ekskursij muzejami svitu [TOP-7 virtual tours of museums around the world]. Available at: https://naurok.com.ua/post/top-7-virtualnih-ekskursiy-muzeyami-svitu (accessed 31 May 2021).

12. Turism chasiv pandemii: sho bide z galuzzu u 2021 roci [Pandemic tourism: what will happen to the industry in 2021]. Available at: https://www.epravda.com.ua/columns/2020/12/3/668768/ (accessed 31 May 2021).

13. Turism pislja pandemii. Chi je perspektiva? [Tourism after the pandemic. Is there a prospect]. Available at: https://rst.if.ua/2020/05/01/turyzm-pislya-pandemiyi-chy-ye-perspektyva/ (accessed 31 May 2021). 